addicts, most of whom had the type of disease found in southern Italy, where delta infection is endemic.

Our results indicate that even among Scandinavian drug addicts chronic hepatitis B virus infection, otherwise a benign condition, may progress to serious liver damage once delta infection supervenes.

This study was supported by a grant from the Swedish Medical Research Council project number B 85-16X-02865-I6 and the Österlund Foundation.

\section{References}

1 Bianchi L, De Groote J, Desmet VJ, et al. Acute and chronic hepatitis revisited. Lance 1977;ii:914-9.

2 Widell A, Hansson BG, Löfgren B, et al. IgM antibody to the hepatitis B core antigen in acute hepatitis determined by SPRIA-diagnostic value. Acta Pathol Microbiol Immunol Scand (B) 1982;90:79-84.

3 Hansson BG, Moestrup T, Widell A, Nordenfelt E. Infection with delta agent in Sweden: introduction of a new hepatitis agent. F Infect Dis 1982;146:472-8.

introduction of a new hepatitis agent. $\mathcal{F}$ Infect Dis $1982 ; 146: 472-8$.
Rizzetto M, Shih JW-K, Gerin JL. The hepatitis B virus-associated delta antigen: isolation from liver development of solid-phase radioimmunoassays for delta antigen and anti-delta and partial characterization of delta antigen. $\mathcal{F}$ I mmunol 1980;125:318-24.

5 Viola LA, Coleman JG, Gluker JL, et al. Natural history of liver disease in chronic HBsAg carriers. Lancet 1981;ii:1156-9.
6 Hall AJ, Sevens H, Wright R. Liver disease in HBsAg carriers. Lancet 1981;ii: 1428.

7 Nordenfelt E, Lindholm T, Löfgren B, et al. Different categories of chronic HBsAg carriers: a long term follow up. In: Szmuness E, Alter H, Maynard J, eds. Viral hepatitis, 1981. long term follow up. In: Szmuness E, Alter H, Maynard J,

8 Davis GL, Hoofnagle GJ, Waggoner JG. Spontaneous reactivation of chronic hepatitis B virus infection. Gastroenterology 1984;86:230-5.

9 Norkrans G, Frösner G, Hermodsson S, Iwarson S. Multiple hepatitis attacks in drug addicts. JAMA 1980;243:1056-8.

10 Mosley JW, Redeker AG, Feinstone SM, Purcell RH. Multiple hepatitis viruses in multiple attacks of acute viral hepatitis. $N$ Engl F Med 1977;296:75-80.

1 Farci P, Smedile A, Lavarini C, et al. Delta hepatitis in inapparent carriers of $\mathrm{HBsAg}$. Gastroenterology 1983;85:669-73.

12 Norkrans G. Clinical, epidemiological and prognostic aspects of hepatitis A, B and non-A, non-B. Scand I Infect Dis 1978; suppl 17:7.

13 Kryger P, Hofmann B, Strandberg Pedersen N, et al. Hepatitis blandt homosexuelle i 2 Københavnske saunaer. Ugeskr Laeger 1984;146:1276-9.

14 Simmons PD, Islam MN, Knott S, et al. e Antigen among male homosexual patients. Br Med $\mathcal{F}$ 1977;ii: 1458 .

15 Aldershvile K, Skin ö P, Frösner G, et al. The expression pattern of $\mathrm{HBeAg}$ and $\mathrm{Ab}$ in different ethnic and clinical groups of HBsAg carriers. I Infect Dis 1980;142:18-22.

16 Mavligit G, Talpaz T, Hsia F, et al. Chronic immune stimulation by sperm alloantigens. fAMA 1984;251:237-41

17 Anderson MG, Eddleston ALWF, Murray-Lyon JM. Altered natural history of hepatitis B in homosexual males_a reflection of altered immune responsiveness. F Med Virol 1985;17:167-73.

18 Sagnelli E, Piccinino F, Pasquale G, et al. Delta agent infection: an unfavourable event in $\mathrm{HBsAg}$ positive chronic hepatitis. Liver 1984;4:170-6.

19 Rizzetto M, Verme G, Recchia S, et al. Chronic hepatitis in carriers of $\mathrm{HBsAg}$ with intrahepatic expression of delta antigen. Ann Intern Med 1983;98:437-41.

(Accepted 6 fanuary 1986)

\title{
Synthesis of histamine by Haemophilus influenzae
}

\author{
BRYAN D SHEINMAN, JAGDISH L DEVALIA, ROBERT J DAVIES, SUSAN J CROOK, \\ SOAD TABAQCHALI
}

\begin{abstract}
Recent findings suggest that bacteria might contribute to histamine concentrations in the sputum of patients with infective lung disease. Ten isolates of Haemophilus influenzae from patients with acute exacerbation of chronic bronchitis and emphysema, together with two reference strains, were incubated at $37^{\circ} \mathrm{C}$ for 72 hours. Serial estimations of histamine concentrations by high pressure liquid chromatography showed significant increases at 24 and 48 hours; no increases were evident in the control samples. These findings suggest that $H$ influenzae might contribute to inflammation and limited airflow in infective lung disease by producing histamine.
\end{abstract}

\section{Introduction}

We recently showed large quantities of histamine in the sputum of patients with chronic bronchitis and cystic fibrosis; concentrations increased substantially when samples were incubated at $37^{\circ} \mathrm{C}$. This phenomenon was prevented both by heating samples at $100^{\circ} \mathrm{C}$ before incubation and by adding antibiotics, suggesting bacterial

\footnotetext{
Academic Department of Respiratory Medicine, St Bartholomew's Hospital, London EC1

BRYAN D SHEINMAN, BPHARM, MRCP, research fellow

JAGDISH L DEVALIA, MSC, PHD, research scientist

ROBERT J DAVIES, MD, FRCP, reader in respiratory medicine

Department of Medical Microbiology, St Bartholomew's Hospital, London SUSAN J CROOK, MB, MRCPATH, senior registrar

SOAD TABAQCHALI, MB, MRCPATH, reader in medical microbiology

Correspondence to: Dr Davies.
}

synthesis of histamine. ${ }^{1}$ As the experiments did not clearly indicate which species might be responsible we investigated the ability of organisms commonly isolated from sputum to synthesise histamine. We report here our findings for Haemophilus influenzae, a common respiratory pathogen.

\section{Methods}

The strains of $H$ influenzae studied included 10 isolates from patients with acute exacerbation of chronic bronchitis and emphysema and reference strains NCTC 8467 Pittman type b and NCTC 7918 Pittman type f (now uncapsulated). The culture medium used was a modified trypticase soy broth supplemented with histidine $(1 \mathrm{~g} / \mathrm{l})$, pyridoxine $(5 \mathrm{mg} / \mathrm{l})$, and $5 \%$ Fildes extract (Oxoid Ltd, UK). Each strain was incubated in trypticase soy broth at $37^{\circ} \mathrm{C}$ overnight, and $1 \mathrm{ml}$ of this culture was then added to $20 \mathrm{ml}$ trypticase soy broth in a sterile polypropylene container, which was incubated at $37^{\circ} \mathrm{C}$ for 48 hours with gentle agitation. Samples taken for histamine analysis were stored at $-20^{\circ} \mathrm{C}$. Histamine was analysed by high performance liquid chromatography. ${ }^{2}$

Duplicate cultures of the 12 strains were prepared as above. Histamine concentration was estimated at 0 and 48 hours and purity plates inoculated to check for contamination. Bacteria were counted at 48 hours. Two broths that had not been inoculated were included as negative controls. To check reproducibility four replicate cultures of two isolates found to produce histamine were set up and samples taken at 0,24 , and 48 hours. Duplicate cultures of one strain that produced histamine were also set up as above and samples taken at 0 , two, four, six, nine, 12, 24, 31, and 48 hours for histamine analysis and bacterial counts.

\section{Results}

Seven of the 12 isolates produced histamine, the concentration in the culture medium increasing in the range $127-3360 \%$. All replicates showed highly significant increases in histamine concentrations at 24 and 48 hours $(p<0.01$ and $p<0.001$ respectively). Controls showed no increases. The figure shows the relation between bacterial growth and production of 


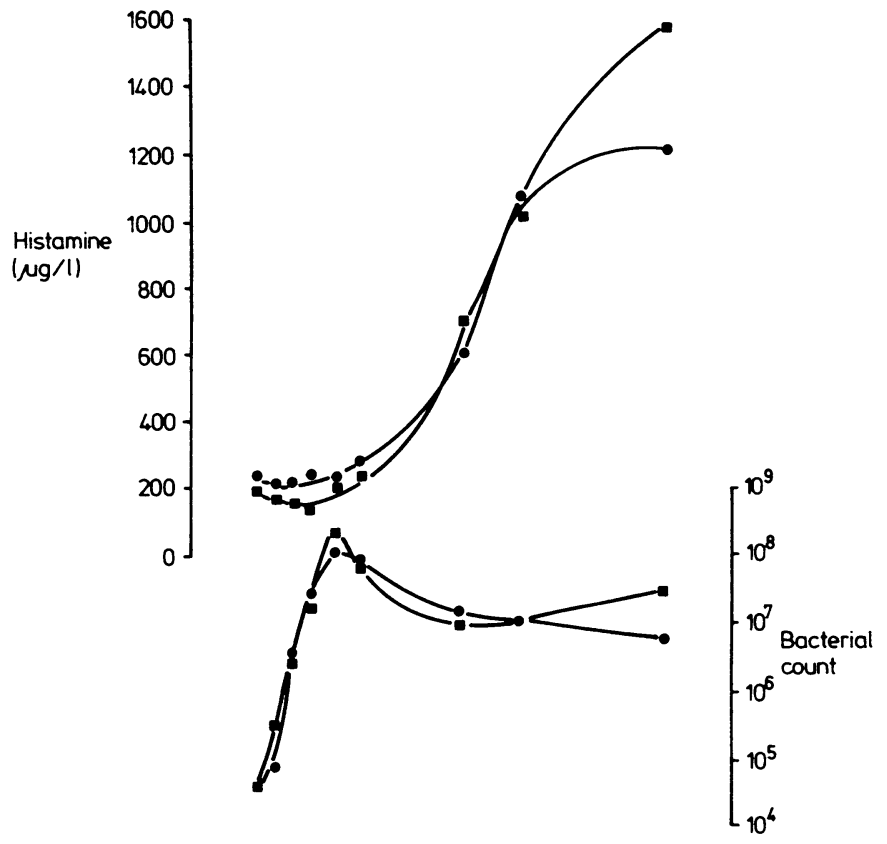

\begin{tabular}{lllllll}
\hline 0 & 8 & 16 & 24 & 32 & 40 & 48
\end{tabular}

Relation between histamine concentration in culture medium and bacterial growth in duplicate cultures.

histamine for one isolate in duplicate cultures: histamine is produced during the stationary phase. High pressure liquid chromatography mobile phase adjustment, treatment with diamine oxidase, and thin layer chromatography all confirmed the presence of histamine in cultures. Extracts of cultures induced contraction in preparations of isolated guinea pig ileum, a reaction that showed dose related antagonism by mepyramine.

\section{Discussion}

Histamine concentrations in sputum in infective lung disease are $\frac{3}{\mathrm{D}}$ high and comparable with those found in asthma, though mast cells $\stackrel{\varrho}{c}$ seem a less likely source. Synthesis of histamine has previously been shown in a variety of bacterial species, mainly Gram negative $\frac{\rho}{\bar{F}}$ organisms. Indeed, high histamine concentrations in the tissues of fish probably account for the symptoms and signs associated with the ingestion of spoiled Scombresocidae and Scombridae such as tunam and mackerel and possibly other species. Bacteria that have been? implicated include Proteus spp, Klebsiella pneumoniae, Enterobacter $\Rightarrow$ aerogenes, Clostridium perfringens, and some species of hafnia, vibrio, $\stackrel{\oplus}{+}$ providencia, citrobacter, and lactobacillus. ${ }^{34}$ This is the first report? of synthesis of histamine by $H$ influenzae.

Effects of histamine on the lung include constriction of smooth $\frac{\bar{s}}{7}$ muscle, stimulation of vagal afferent nerve endings and mucousळ glands, and increased permeability of bronchial epithelium..$^{5}$ Our results suggest that $H$ influenzae might contribute to inflammation $\vec{\theta}$ and limited airflow in infective lung disease by producing this highly potent biogenic amine.

We thank Dr Donald Mason and Mr Neal Moses (department of pharmacology, Medical College of St Bartholomew's Hospital) for facilitiesĩ for the experiments with guinea pig ileum, and the joint research board of the hospital for financial support.

\section{References}

I Sheinman BD, Devalia JL, Crook SJ, Davies RJ. De novo generation of histamine in sputum and the effect of antibiotics. Agents Actions (in press).

2 Devalia JL Sheinman BD, Davies RJ. A new high-performance liquid chromatographic for the assay of histamine, 1 -methyl histamine and other biogenic amines. $f$ Chromatogn 1985:343:407-12. 3 Taylor SL, Guthertz LS, Leatherwood M, Tillman F, Lieber ER. Histamine production by foodborne bacterial species. Journal of Food Safety 1978;1:173-87.

4 Arnold SH, Brown WD. Histamine (?) toxicity from fish products. Adv Food Res 1978;24:113-54 . 5 Boucher RC, Ranga V, Pare PD, Inoue S, Moroz LA, Hogg JC. Effect of histamine and methacholine on guinea-pig tracheal permeability to HRP. F A ppl Physiol 1978;45:939-48.

(Accepted 3 Fehruary 1986)

\section{YEARS AGO}

\section{A CANDIDATE FOR A DRUNKARD'S RETREAT}

Under this heading, a daily contemporary has reported an application by two gentlemen, on behalf of a third person, for admission into a "drunkard's retreat." The applicant was described as "rather strange in his manner," and was cross-examined by the magistrate as to his knowledge of the provisions of the Acts under which he wished to be detained.

The Acts in question were only passed after strenuous efforts; and the difficulties inherent to these and similar enactments were only overcome by much devotedness on the part of those philanthropic persons who have made the treatment and cure of the inebriate the object and purpose of their life. It might have been hoped, therefore, that so much self-abnegation and goodwill would meet with due appreciation and assistance at the hands of those who, in their official capacity, are called upon to intervene in the case, as well as by the general public. We cannot say that these hopes and anticipations have been altogether realised. From time to time a crotchety magistrate has prolonged a painful situation by unnecessary quibbles; while the police authorities, who are perhaps naturally disposed to look upon "running in" as a sovereign remedy for inebriety, do not always show that alacrity in acting up to their instructions which might reasonably be expected. These little hindrances, however, hamper rather than prevent due recourse from being had to these homes; but such cannot be said of the practice for which a precedent has now been established. If the unhappy victim of a degrading vice is to be labelled forthwith as an "applicant for admission to a drunkard's retreat," his name and his shame blazoned forth in all the daily papers, with a reversionary interest in a heritage of shame, while he is cross-examined in open court as to his acquaintance with the details of the law under which he consents to alienate his liberty for a time, then we may be sure that the number of applications will be small.

It is already difficult to bring the repentant sinner to make and indict a formal confession of his failing; and if the publicity, which is alreads unjustifiable in ordinary police reports, is, in future, to be accorded to these particular cases, no one, with enough self-respect left to desire reformation will be induced to face the unutterable shame of such a declaration.

We would, in the first instance, appeal to the Press generally to declinê such contributions; and, should this fail, it would not be amiss to take measures for the introduction of a Bill which shall deal with the question og publicity - at any rate, as far as names are concerned —of affairs of simpl police. The very least that can be done will be to cause such applications to ber made in camerâ ; and, possibly, means may ultimately be found whereby the intervention of so public a functionary as a magistrate may be avoided.

Justice and mercy suggest the propriety of throwing a veil over the frailtien of our fellows, especially when the very effort indicates a desire to regain selfN command, and avoid the inevitable consequences of a degrading vice.

The reports of these homes are, on the whole, encouraging. Even where:o cure has not been effected, the good is beyond and above suspicion. Everte march stolen on so redoubtable an enemy as habitual drunkenness, is a achievement of which the temperance church militant may justly be proud $\stackrel{?}{\rightarrow}$ and will serve to encourage further efforts in the same direction. Of course where inebriety is only the expression of what we may term a "neurotie diathesis," the good can only be temporary, and the benefit from treatmeng in such cases is not to be measured by the permanency of its results; bu既 many - and, doubtless, the vast majority - of cases of chronic inebriety, are attributable simply to the besotting influence of pernicious social customscustoms which we are glad to see surely, if slowly, becoming less general. IB this class, the work may be undertaken with fair hope of lasting success, an the advocates of this method of temporary restraint may legitimately call o their friends to "rejoice over one sinner that repenteth." (British Medicas Foumal 1886;ii:28.) 